\title{
Analysis of Government Stimulus Policy Facing the Covid-19 Pandemic on Abnormal Share Returns (Study on LQ-45 Shares)
}

\author{
Asriyatuzzahra $^{1 *}$, Nida Muti Fatimah ${ }^{1}$, Ida Maftukhah ${ }^{1}$ \\ ${ }^{I}$ Management Study Program, Faculty of Economics, Semarang State University \\ *Corresponding author. Email: asriyatuzzahra@gmail.com
}

\begin{abstract}
The corona virus disease in 2019 (Covid-19) globally has had a direct or indirect impact on the performance and capacity of debtors in fulfilling credit or financing payment obligations. The spread of Covid-19 also has an impact on the performance and capacity of debtors and increases credit risk which has the potential to disrupt banking performance and financial system stability so that it can affect economic growth. To encourage optimization of banking performance during this pandemic, particularly the intermediation function, maintaining financial system stability and supporting economic growth, economic policies are needed to stabilize the country's economy. This study aims to determine the difference in abnormal returns before and after the economic stimulus policies announcement in dealing with Covid-19 pandemic. This study used a case study approach, with an observation period of 5 days before and 5 days after. The sample used in this study was 45 companies listed in the LQ- 45 index. The data were analyzed using paired sample T-test. The results of this study indicate that when the economic stimulus announcement came out on February 24, 2020, there was a difference in the average abnormal return on LQ-45 stocks.
\end{abstract}

Keywords: Abnormal Return, Covid-19, LQ-45, Study Event, Pandemic

\section{INTRODUCTION}

An important breakthrough in the theory of corporate finance issued by [1] is the theory of efficient markets. A market is said to be efficient if no one, either individual or institutional investors, will be able to get an abnormal return after adjusting for risk and using existing trading strategies. In it serialization, there is a pattern mismatch regarding the evidence obtained from research on seasonal patterns of stock returns. These patterns seem to contradict theoretical notions of market efficiency. This discrepancy is called

The most commonly used models are the market model or the single index model and the Capital Asset Pricing Model. Abnormal returns emerge as a result of a market reaction to an announcement. The influence of the economic environment includes both the micro and macro environments. The micro environment such as company performance, corporate strategy policies (for example, merger or acquisition policies), announcements of financial statements or company dividends always get responses from market players in the capital market. The macro environment, such as changes in savings and time deposit interest rates, foreign exchange rates, inflation, as well as various regulations and deregulations issued by the government, which also have an effect on price fluctuations. The more important the role of the capital market in a country's economy, the more sensitive it is to various events in its surroundings [12]. This information will provide a signal for investors in making investment decisions so that they also have an effect on price fluctuations and trading volume in the capital market. When the information is announced and all market players have received the information, market players will first interpret and analyze the information as a good news or bad news. To measure investor's reactions against 
some information, it is indicated by changes in stock prices as measured by looking at abnormal returns. If an event does not cause an abnormal return, it means that investors do not react or there is no market reaction, because the reaction by investors to the new information is indicated by an abnormal return [4].

According to [4], testing the information content is intended to see the reaction of an announcement. If the announcement contains information, it is expected that the market will react when the announcement is received by the market. Market reaction is indicated by a change in the price of the security involved. This reaction can be measured by using return as the value of price changes or by using abnormal returns. If an abnormal return is used, it can be said that an announcement that contains information will give an abnormal return to the market. Conversely, those that do not contain information will not provide an abnormal return to the market.

As an economic instrument, the capital market cannot be separated from various environmental influences, both the economic and non-economic environment. Such as the spread of the corona virus disease in 2019 (Covid-19) globally has had a direct or indirect impact on the performance and capacity of debtors in fulfilling credit or financing payment obligations. The spread of Covid-19 also has an impact on the performance and capacity of debtors and increases credit risk which has the potential to disrupt banking performance and financial system stability so that it can affect economic growth. To encourage optimization of banking performance during this pandemic, particularly the intermediation function, maintaining financial system stability and supporting economic growth, economic policies are needed to stabilize the country's economy.

The economic stimulus policy as a countercyclical impact of the spread of Covid-19 is implemented with due observance of the precautionary principle, that based on the considerations referred to in the paragraph above, Otoritas Jasa Keuangan (OJK) needs to establish a regulation on National Economic Stimulus as a Countercyclical Policy on the Impact of the Spread of Covid-19.

Various event studies have been conducted on events that occur in the issue of external environment and generally only analyze one event. Several previous event studies that have been carried out to analyze the reaction of the Indonesian capital market to domestic economic policies have proven that the content of relevant information in each of these events causes the capital market to react, for example to government policies in reducing the price of fuel oil [11] and research by [10] shows that the market reacts to the announcement of bonuses in several companies listed on the Indian stock exchange. However, on several other economic events there is no evidence of market reaction, for example in the event of an increase in fuel price policies [9], changes in fuel prices to abnormal returns and trading volume activity by [7], on [8] research about the delay in subsidized fuel oil and from [6] research on the parliamentary election, shows that there is no difference in abnormal returns before and after the event.

The purpose of this study is to determine the existence of market reactions as measured by the abnormal return variable in the period 5 days before and after the announcement of the economic stimulus by President Joko Widodo through OJK on February 24, 2020. Based on the description above, the hypothesis development of this study is as follows, there is a difference in abnormal returns in the period before and after the announcement of the economic stimulus in dealing with Covid-19 on February 24, 2020.

The market reaction to the announcement of an economic stimulus can be measured by looking at the level of profit, namely from the abnormal return. According to [5], abnormal return is an excess of return that actually occurs against normal return, which is the return expected by investors (expected return). Abnormal return is the difference between the actual return that occurs with the expected return. The formulation is as follows:

\section{METHOD}

This research is a type of quantitative research, namely research with secondary data taken by the method of documentation. The time period used in this study is 11 days, consisting of t-5 ( 5 days before the event), t0 (day of the event), $t+5$ ( 5 days after event). Determining the event window is done to avoid the effects of other events.

The population used in this study were all companies whose shares were included in the LQ-45 index for the period February-March 2020. The sample selection in this study used a purposive sampling method. The criteria for selecting the sample to be studied such as, stocks that are included in the LQ-45 calculation in the period FebruaryMarch 2020, have a complete data required in this study, stocks are not suspended during the 
observation period, the company does not perform corporate actions during the observation period.

The variables in this research are the events of economic stimulus policy announcements and data on abnormal returns. Abnormal return (AR) of stocks is calculated using the market adjusted model method by finding the difference between the daily returns of each sample and the market index return.

Abnormal return (AR)

$$
A R i, t=R i, t-E[R i, t]
$$

ARit $=$ Rit - Rmt

ARit $=$ Abnormal return

Rit $=$ Current stock return

$\mathrm{Rmt}=$ Market return

The normality test is carried out to determine whether the data variables have a normal distribution or not, the normality test aims to test whether there are confounding variables in the model [3]. Testing for normality in this study using the one sample Kolmogorov-Smirnov test. In the one sample Kolmogorov-Smirnov test if the variables that have asymp. Sig (2- tailed) above the significant level of 0.05 , it means that these variables have a normal distribution and vice versa.

Paired sample T-test is used to determine whether two related samples have different means. The t-test difference test is carried out by comparing the difference between the two mean values and the standard error of the difference between the mean of the two samples. According to [3], the purpose of the t-test difference test is to compare the average of two groups that are not related to one another. By using the significance level $\alpha=5 \%$, the test criteria are as follows. The hypothesis is accepted if the significance value is less than 0.05 , it means that there is a difference of 5 days before and after the announcement of the economic stimulus. The hypothesis is rejected if the significance value is bigger than 0.05 , meaning that there is no difference 5 days before and after the announcement of the economic stimulus.

\section{RESULTS AND DISCUSSION}

\section{Normality test}

The results of the normality test using the Kolmogrov-Smirnov test can be seen in Table 1.
Table 1. Data Normality Test Results.

\begin{tabular}{lll}
\hline \multirow{2}{*}{ No } & \multirow{2}{*}{ Variable } & \multicolumn{2}{l}{ Uji Kolmogrov-Smirnov } \\
\cline { 3 - 3 } & & Asymp. Sig. (2-tailed) \\
\hline 1. & $\mathrm{t}-5$ & .200 \\
\hline 2. & $\mathrm{t}-4$ & .086 \\
\hline 3. & $\mathrm{t}-3$ & .200 \\
\hline 4. & $\mathrm{t}-2$ & .200 \\
\hline 5. & $\mathrm{t}-1$ & .083 \\
\hline 6. & $\mathrm{t}+1$ & .200 \\
\hline 7. & $\mathrm{t}+2$ & .023 \\
\hline 8. & $\mathrm{t}+3$ & .079 \\
\hline 9. & $\mathrm{t}+4$ & .200 \\
\hline 10. & $\mathrm{t}+5$ & .200 \\
\hline
\end{tabular}

Table 1 shows that the normality test on the data for five days before and five days after the event of the announcement of the economic stimulus in dealing with Covid-19 on February 24, 2020 have sig. ( 2 tailed) is greater than 0.05 . So it can be interpreted that the abnormal return of LQ-45 stocks is normally distributed.

Table 2. Paired Sample T-test

\begin{tabular}{lll}
\hline Variable & df & $\begin{array}{l}\text { Sig. } \\
\text { tailed) }\end{array}$ \\
\hline Pair $1 \mathrm{t}-1 \mathrm{t}+1$ & 44 & .009 \\
\hline Pair $2 \mathrm{t}-2 \mathrm{t}+2$ & 44 & .005 \\
\hline Pair $3 \mathrm{t}-3 \mathrm{t}+3$ & 44 & .021 \\
\hline Pair $4 \mathrm{t}-4 \mathrm{t}+4$ & 44 & .000 \\
\hline Pair $5 \mathrm{t}-5 \mathrm{t}+5$ & 44 & .001 \\
\hline
\end{tabular}

The hypothesis in this study is that there is a difference in abnormal returns in the period before and after the announcement of the economic stimulus in dealing with Covid-19 on February 24, 2020. The Paired Sample T-test was carried out with a significance level of 0.05 . The hypothesis is accepted if the significance value is less than 0.05 , it means that there is a difference of 5 days before and after the announcement of the economic stimulus. The hypothesis is rejected if the significance value is bigger than 0.05 , meaning that there is no difference 5 days before and after the announcement of the economic stimulus.

Table 2 shows that the abnormal return of $\mathrm{t}-1$ to $\mathrm{t}-$ 5 before the announcement of economic stimulus in dealing with Covid-19 and $t+1$ to $t+5$ after the event 
of the announcement of economic stimulus in dealing with Covid-19 has sig. ( 2 tailed) $<0.05$ is smaller than the predetermined significant value, so that the hypothesis is accepted. This means that there is a difference in abnormal returns in the period before and after the announcement of the economic stimulus in dealing with Covid-19 on February 24, 2020.

\section{CONCLUSIONS AND SUGGESTION}

Based on the results of the paired sample T-test, it can be concluded that there is a difference in abnormal returns in the 5 days period before and after the economic stimulus announcement event as a countercyclical impact of the spread of Covid-19 on February 24, 2020. This happened because of investors' reaction in considering the announcement event. economic stimulus to overcome the effects of Covid-19, as an event that contains relevant information and is able to make the market react which will affect their investment decisions in the stock market.

Based on the research results that have been described above, there are suggestions that can be given to several parties who will conduct research with the same object or use this research as a basis.

For the world of education, the results of this research are expected to contribute to the development of management science, especially financial management related to non-economic events.

Investors are advised to include elements of both economic and non-economic events in interpreting information related to stock prices as good news or bad news so that investment decisions can provide results in line with investors' expectations. This is because the events that occur have relevant information and are able to make the market react, which in turn can influence their investment decisions in the stock market.

\section{ACKNOWLEDGMENTS}

The researcher expresses his deepest gratitude to all parties who support the implementation of this research, especially for the Ministry. We further thank our supervisor, Mrs. Siti Ridloah, SE., M.Mgmt who always provides suggestions and input for improvement for our team. As well as to the entire reviewer team of the Faculty of Economics, State University of Semarang who have collaborated to assist students in carrying out this research.

\section{REFERENCES}

[1] E.F. Fama, Efficient capital markets: a review of theory and empirical work, J. Finance. 25 (1970) pp 383-417. https://doi.org/10.1016/00028703(53)90182-3.

[2] H. Jogiyanto, Teori Portofolio dan Analisis Investasi Edisi Kedelapan, Edisi 8, Yogyakarta: BPFE, 2013.

[3] I.W. Suarjana, Pengaruh kebijakan pemerintah dalam menurunkan harga bahan bakar minyak terhadap reaksi pasar saham di bursa efek indonesia, Thesis Pascasarj. (2011).

[4] M. Raja, J.C. Sudhahar, an Empirical Test of Indian Stock Market Efficiency in Respect of Bonus Announcement., Asia Pacific J. Financ. Bank. Res. 4 (2010), pp 1-14.

[5] M. Mufarrocha, Sinarwati, S. Werastuti, Analisa Pasar dalam Merespon Penundaan Kenaikan Harga BBM Bersubsidi di Bursa Efek Indonesia ( Event Study terhadap Peristiwa Penundaan Kenaikan Harga BBM Bersubsidi oleh Presiden Susilo Bambang Yudhoyono ), E-Journal S1 Ak Univ. Pendidik. Ganesha. 3 (2015).

[6] S. Lehander, Parliamentary Elections " Impact on Stock Market Returns, (2011), pp $1-74$.

[7] G. Imam, Aplikasi Analisis Multivariate Program IBM SPSS 19, badan penerbit universitas diponegoro, Semarang, 2011. 